\title{
Korpus, kieli ja käytänteet
}

"Lähivõrdlusi. Lähivertailuja" ilmestyy nyt jo 24. kerran, ja jo kuudennen kerran tässä nykyisessä muodossaan Viron soveltavan kielitieteen yhdistyksen julkaisuna, sekä paperilla että verkossa. Olemme ylpeitä ja onnellisia tästä viime vuosina yhä mittavammaksi paisuneesta kansainvälisestä sarjastamme, johon jatkuvasti tarjotaan eriaiheisia kirjoituksia suomen, viron ja muiden suomalais-ugrilaisten kielten käytön, oppimisen ja opettamisen kysymyksistä. Vaikuttaa siltä, että julkaisumme on vakiinnuttanut paikkansa ja suomensukuisten kielten soveltavasta tutkimuksesta kiinnostunut yleisö on löytänyt "Lähivertailut" - luonnollisesti toivotamme sydämellisesti tervetulleiksi myös kaikki uudet lukijat ja kirjoittajat.

Tämän sarjan 24. numeron artikkeleista osa pohjautuu jälleen kerran "Lähivertailujen" alaan läheisesti liittyvään konferenssiin: niiden ensimmäisenä esitysympäristönä oli työpaja, jonka Suomen soveltavan kielitieteen yhdistyksen AFinLA:n syyssymposiumin 2013 yhteydessä järjesti VIRSU, suomalais-ugrilaisia kieliä kohdekielinä tutkiva verkosto. Osa kirjoituksista taas perustuu muualla esiteltyyn tutkimukseen.

Niin kuin jo usein "Lähivertailujen" artikkeleissa aineistona on nytkin useilla kirjoittajilla jokin oppijankielen korpus. Pille Eslon käsittelee artikkelissaan adverbin sisältävien konstruktioiden funktioita viron kaunokirjallisuuden kielessä ja oppijankielessä, aineistonaan Tarton yliopiston kirjakielen korpus sekä viron välikielen korpus. Vironkielisessä kaunokirjallisuudessa adverbikonstruktiot toimivat tärkeänä tekstikoheesion ja -sujuvuuden rakentamisen keinona, kun taas oppijanvirossa niiden käyttö on marginaalista ja stereotyyppistä. Vaikka molemmissa kielimuodoissa käytetään samoja rakenteita, oppijankielessä sekä leksikaalinen että morfosyntaktinen variaatio on huomattavasti rajoittuneempi. 
Jyväskylän yliopiston Cefling-korpusta puolestaan ovat käyttäneet tutkimustensa aineistona Outi Toropainen ja Nina Reiman sekä Marja Seilonen. Toropaisen artikkeli käsittelee tehtävänannossa käytetyn sanan tai samaan sanaperheeseen kuuluvan sanan toistumista oppijoiden tekstissä. Reimanin artikkeli käsittelee transitiivisuutta, mutta toisaalta siinä sivutaan tehtävänannon vaikutusta, ja näitä tuloksia voi tarkastella myös Toropaisen artikkelin rinnalla. Seilonen puolestaan käyttää tutkimuksessaan Cefling-aineistoa ottaen huomioon myös informanttien taustatiedot: hän on valinnut tutkittavakseen terveydenhuollon alan työntekijöiden kielenkäyttöä. Seilonen on huomannut kyseisten informanttien kielellisen asiantuntijuuden heijastuvan myös heidän testiteksteihinsä.

Tuija Määttä jatkaa ruotsinkielisten alkeisoppijoiden kielitaidon kartoitusta ICLFI-korpuksen (International Corpus of Learner Finnish) aineistosta. Tästä eri tutkijat saavat vertailuaineistoa vastaavan kaltaisia kartoituksia tehdessään. Ilmari Ivaskan aineistona taas on LAS2-korpukseen tallennettu edistyneiden oppijoiden suomi ja erityisesti yksi akateemisen kirjoittamisen tekstilajeista, tenttivastaus. Tutkimuksessa vertaillaan tyypillistä akateemisen kirjoittamisen keinoa, mahdollisuuden ilmaisemista voida-verbin avulla, edistyneiden oppijoiden ja ensikielisten suomeksi kirjoittavien opiskelijoiden teksteissä.

Ekspressiiviverbeihin, joita Marjatta Jomppanen käsitteli LV 21:ssä saamen kielen koloratiivikonstruktioiden kannalta, palaa nyt MariaMagdalena Jürvetson. Hänen artikkelinsa aineisto ja lähtökohta on hieman erilainen: pääkysymyksenä on, miten kyselytestimenetelmän avulla voi kartoittaa äidinkielisten näkemyksiä ekspressiiviverbien merkityksistä ja merkitysvivahteista. Näin saadaan tarkempaa ja ajantasaisempaa tietoa kuin mikään sanakirja pystyy antamaan, ja tämä tieto palvelee myös kielenoppijaa ja opettajaa ekspressiiviverbien tulkinnassa.

Leena Niiranen kirjoittaa tuiki tärkeästä ja vähän tunnetusta aiheesta, Norjan kveenin eli kainunkielen elvyttämisyrityksistä päiväkodeissa, joissa ns. kielipesämenetelmää on yritetty soveltaa. Artikkelissa kielipesätoimintaa ja sen onnistumisen edellytyksiä pohditaan Yrjö Engeströmin kehittämän toiminnan teorian pohjalta. 
Pirkko Muikku-Werner käsittelee, kuten jo "Lähivertailujen" numeroissa 22 (yhdessä Maria Heinosen kanssa) ja 23, viron kielen ymmärtämistä suomen kielen pohjalta. Samankaltaisuuden ohella tärkeäksi nousee koteksti, jonka vaikutus voi olla sekä positiivinen että negatiivinen.

Tässä julkaisussa kuten aiemmissakin "Lähivertailuja”-julkaisuissa on sekä katsauksia että artikkeleita. Kirjoituksia ei kuitenkaan ole ryhmitelty lajin perusteella, koska kaikki kirjoitukset on arvioitu tieteellisen aikakauslehden yleisten arviointi- ja toimittamisperiaatteiden mukaan.

Kiitos kirjoittajille monipuolisista artikkeleista ja arvioijille arvokkaista kommenteista, joita kirjoittajat ovat huolellisesti hyödyntäneet. Erityinen kiitos taloudellisesta tuesta, jota olemme saaneet Alfred Kordelinin yleisen edistys- ja sivistysrahaston Viron säätiöltä, Suomalais-ugrilaisen kulttuurirahaston säätiöltä ja Viron opetus- ja tiedeministeriön valtakunnalliselta ohjelmalta "Viron kieli ja kulttuurimuisti II". Erittäin tärkeänä pidämme sitä, että saamme julkaista "Lähivõrdlusi. Lähivertailuja” Viron soveltavan kielitieteen yhdistyksen suojissa. Kiitos tästä.

Tallinnassa, Wienissä ja Turussa

Annekatrin Kaivapalu, Johanna Laakso, Kirsti Siitonen ja

Katre Oim 